\title{
13
}

\section{Australia's employment services, 1998-2012: Using performance monitoring and evaluation to improve value for money}

\author{
Wendy Jarvie and Trish Mercer
}

\section{The reform of employment services delivery in Australia}

Australia, together with the Netherlands, has been recognised as a world leader in the introduction of market competition for the provision of employment assistance to unemployed jobseekers. Yet as Struyven (2004: 3) has observed, the creation of a quasi-market in employment service provision is not a simple choice for government and requires a continual and complex 'balancing act' between government regulation and creating sufficient room for market competition, and also between the goals of efficiency and equity. This chapter investigates the intensive evaluation and performance monitoring processes that the Australian Government invested in and utilised over the 15 years from 1998 to support the development and fine-tuning of the market delivery of employment services, and to drive continual improvement in value for money. 
In the early 1990s, a period of experimentation had begun in the delivery of employment assistance, which is a national government function in Australia. The Labor Government of Paul Keating had moved beyond the traditional provision of such assistance by its public provider (the Commonwealth Employment Service) to encourage contestability in employment services, including an innovative case management approach for the long-term unemployed delivered by the community sector and private contracted case managers and a billion-dollar investment in training programs under the Working Nation program (Davidson and Whiteford 2012: 53). By 1995, the last year of the Keating Government, the annual cost of employment and labour market assistance programs was over $\$ 4$ billion. Following the election of John Howard's Coalition Government in 1996, what was seen as a more radical experiment was introduced, in May 1998, which involved the Department of Employment ${ }^{1}$ contracting a Job Network of community-based and private providers who would provide employment assistance to unemployed jobseekers and also employers (Thomas 2007: 1-2). While it delivered significant budget savings, this reform, the government contended, would address known deficiencies in the current provision of employment assistance, which had not achieved any significant difference in getting the unemployed into regular employment, while retaining the case management approach with its emphasis on flexible and individualised assistance. At the same time, the government tightened the requirements on those receiving unemployment benefits to actively look for work (known as 'activity testing') and increased the sanctions for failing to do so (Thomas 2007: $10-11)$.

The rationale for outsourcing employment services was that it would ensure a greater focus on achieving outcomes for clients at lower cost to government through:

1. paying for client outcomes rather than inputs

2. creating competition between providers for

a. employment services contracts (through tendering arrangements)

b. jobseeker clients (who could choose their employment service provider).

1 The Department of Employment has experienced a number of machinery-of-government (and thus name) changes since 1998. For simplicity, it is referred to as the Department of Employment in this chapter. 
It was thus intended to focus provider strategies, energies and resources on achieving outcomes for clients, at the lowest costs possible, and not on providing activities for clients to do. This was in line with the prevailing New Public Management (NPM) public administration theory to shift focus from inputs to outcomes. A declared objective of the reforms was to obtain better value for money (PC 2002: 3.2).

The Job Network system was managed by the Department of Employment (for an explanation of its role, see Appendix 13.1). It operated through the referral by the newly established public benefits agency, Centrelink, of jobseekers receiving government income support to the contracted providers, who had flexibility in determining what 'employment assistance' (rather than a conventional labour market program, as under the previous system) would be appropriate for an individual jobseeker. Fees paid to providers comprised two components: one fee when a jobseeker commenced with them and a second when an employment or other outcome was obtained. Fees were on a sliding scale, with higher fees set for those who remained in employment for 26 weeks or more. Fees for both components also varied depending on the level of jobseeker disadvantage the client faced, as assessed by Centrelink through the Job Seeker Classification Instrument (JSCI). The higher fees were intended to offer providers an incentive to make the greater effort required to help more disadvantaged jobseekers.

While the key principles of the system remained unchanged—such as having contracted employment service providers and payments for outcomes-the system itself underwent significant development and modification between 1998 and 2012. Broadly, there were three main phases (see Table 13.1):

1. The Job Network 'Black-box'2 Market (1998-2003): The initial development phase, in which contracted providers had significant discretion as to what 'employment assistance' they provided and which focused on outcomes over processes (i.e. 'black-box' methods).

2. The Job Network 'Regulated Market'(2003-09) (also called the Active Participation Model [APM]): The second phase, in which there were increased government regulation and monitoring of providers with

2 This was the term commonly used for this first phase of the Job Network. 
a prescribed continuum of services for jobseekers, in response to the discovery that providers were not investing sufficient resources in their most disadvantaged jobseekers.

3. The Job Services Australia (JSA) 'Inclusive Market' (2009-12): The revamping of the system under the new Labor Government of Kevin Rudd, which rolled seven schemes into one with four 'streams' of assistance for the unemployed, greater focus on the most disadvantaged and more transparent provider star ratings.

\section{Improving value for money}

The budgetary gains for the government from introducing the Job Network were evident from the outset: there was an immediate reduction in the national budget spent on active labour market programs, from \$4.08 billion in 1995-96 to \$2.56 billion in 1998-99 (Organisation for Economic Co-operation and Development [OECD] 2001: 205). There was an associated decline in gross domestic product (GDP) spending on active labour market programs, from 0.8 per cent to 0.4 per cent over two years (OECD 2001: 13).

As well as clear budget savings, there were significant reductions in the average cost per employment outcome. ${ }^{3}$ The employment department, in its evaluation report in 2002, estimated that Job Network costs per employment outcome were the lowest achieved in the previous decade: about $\$ 5,000-\$ 6,000$ since mid-1998, compared with between $\$ 10,000$ and $\$ 16,000$ under Labor's Working Nation programs in the mid-1990s (DEWR 2002b: 4). This decline in costs per employment outcome had been produced through both lower unit costs and higher employment outcomes (Davidson and Whiteford 2012: 108).

The marked change in cost per employment outcome is shown in Figure 13.1. Over time, moreover, this cost continued to decline (Figure 13.2). The sustainability of outcomes achieved by jobseekers was maintained, together with improvements in net impact. ${ }^{4}$ Surveys

3 'Cost per employment outcome' is the average unit cost of all programs divided by the proportion of participants in employment three months after leaving the program (Davidson and Whiteford 2012: 108).

4 Net impact is the measure of the difference that employment services have made to clients' expected outcomes without assistance. See, for example, DEWR (2003: 98). 
showed that both employers and jobseekers were happier with the new arrangements, and the model of provision proved to have sufficient flexibility to deal with changes to labour market conditions, including the reductions in unemployment, the emergence of skills shortages up to 2007 and the worsening employment situation with the Global Financial Crisis (GFC) of 2008. The effectiveness, including cost-effectiveness, of this model of service delivery has been recognised by the OECD (2001: 20; 2012: 13), external researchers (Thomas 2007: 15; Davidson and Whiteford 2012: 57) and through an independent review by the government's research and evaluation body, the Productivity Commission, in 2002. ${ }^{5}$ Clearly, the government's objective of improving value for money was being met.

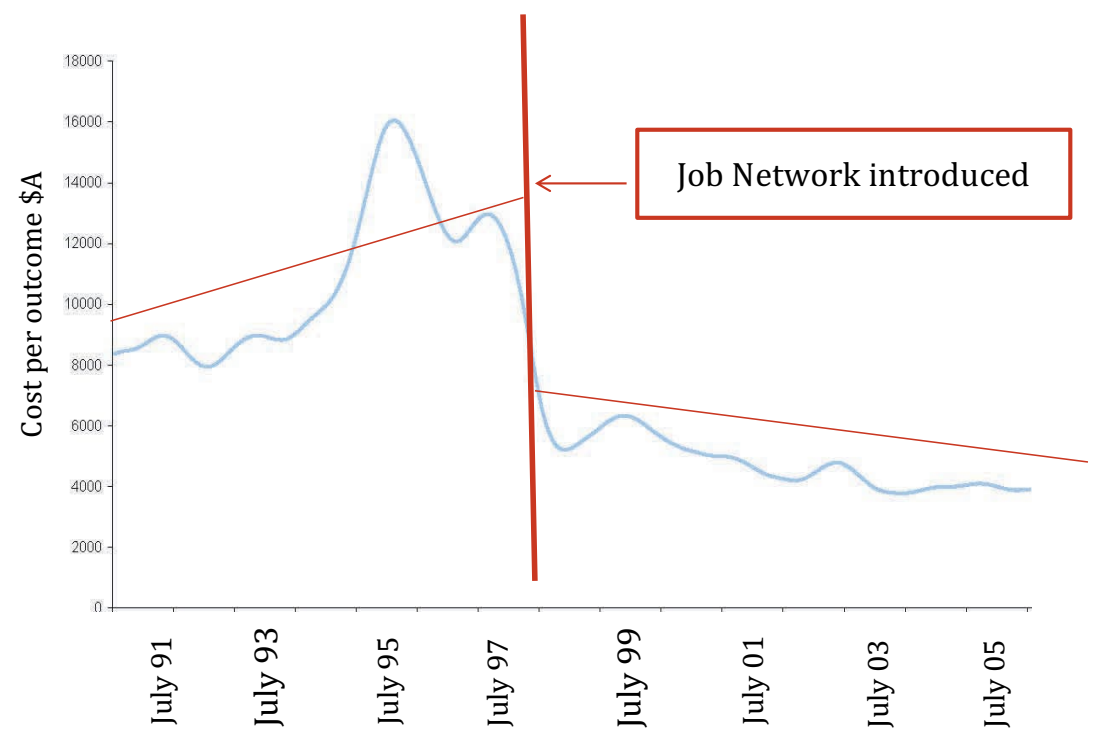

Figure 13.1 Decline in cost per employment outcome, 1991-2006 Source: DEEWR (2007: 138).

5 This report, released in June 2002, contained some criticism of elements of the Job Network system, but was supportive overall, concluding that the advantages of the new market for employment services 'outweigh its limitations' because 'it sets out clear objectives, provides stronger incentives for finding ways of achieving job outcomes and encourages cost efficiency' (PC 2002: xxvi, xxxiii). 
VALUE FOR MONEY

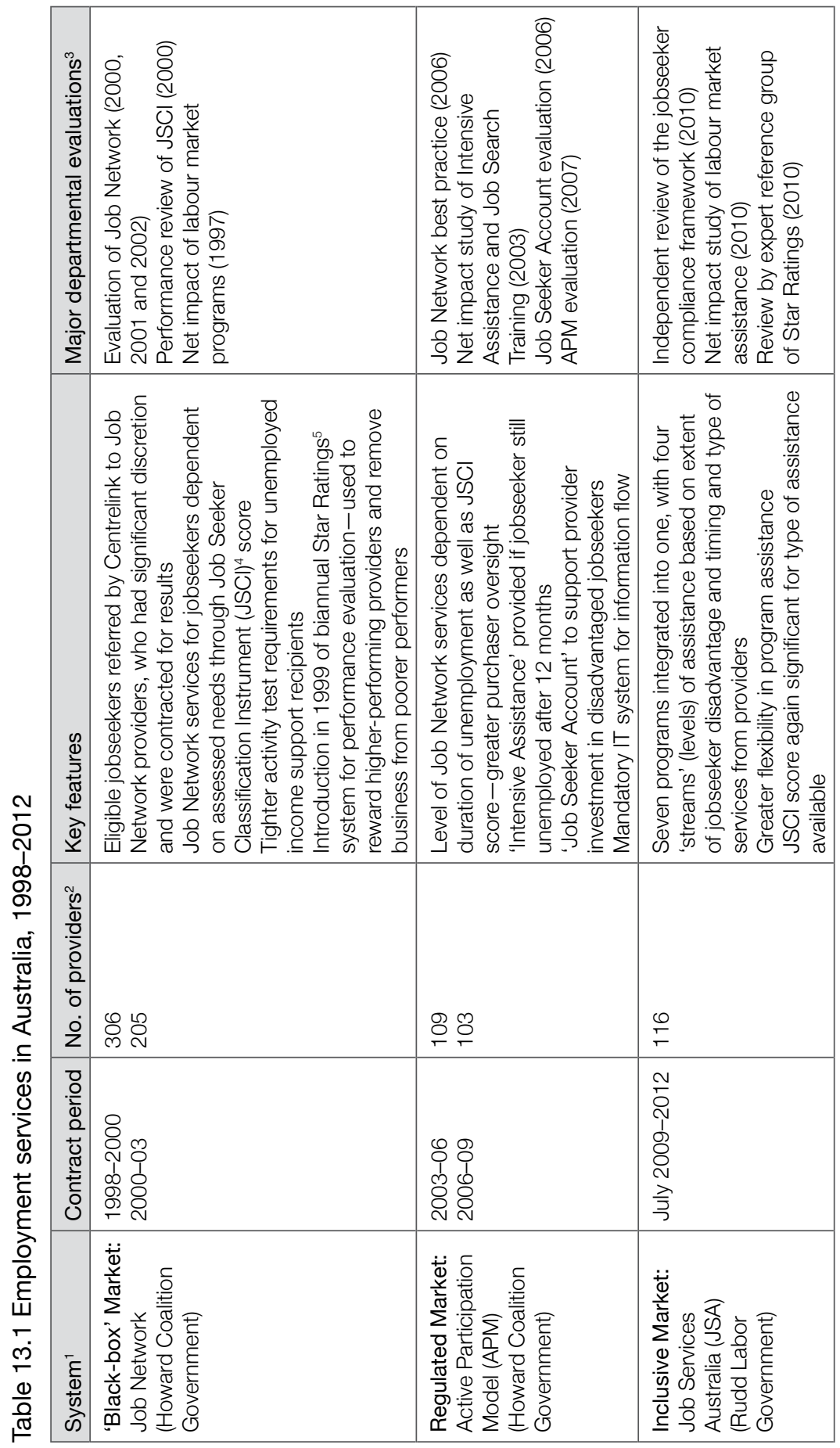


${ }^{1}$ Descriptors from Considine and O'Sullivan (2014).

2 Taken from OECD (2012: 76).

${ }^{3}$ Conducted by officers in the employment department or commissioned from experts with departmental support.

${ }^{4}$ Tool that assesses how difficult it will be for the jobseeker to find employment.

${ }^{5}$ A performance management system developed by the employment department that gives providers a rating (between one and five stars) based on their comparative performance in achieving employment or educational outcomes for jobseekers.

Sources: Davidson and Whiteford (2012); OECD (2012); Borland (2014); Considine and O'Sullivan (2014).

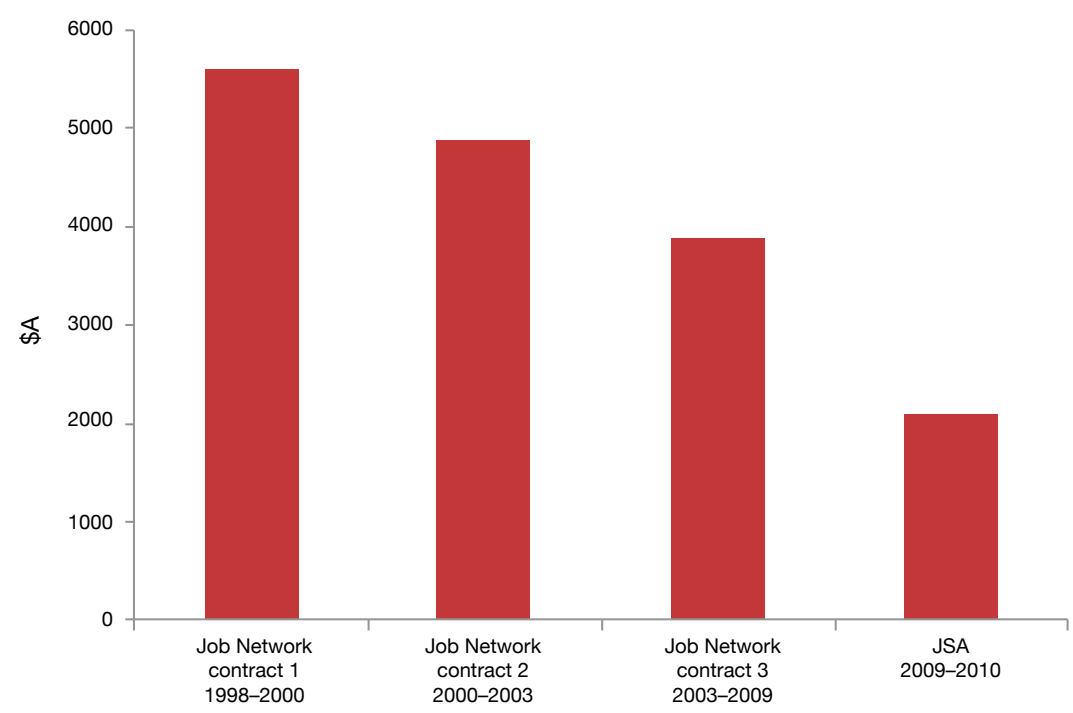

Figure 13.2 Cost per employment outcome

Source: Data from DEEWR (2011).

\section{Evaluation and its role in program design and management}

The cost-per-outcome estimates, together with estimates of net impact and other analyses, such as identifying which jobseekers were being successfully assisted and which were less well supported, were obtained from a comprehensive and sustained evaluation and monitoring program that began in 1998 and was continued under both Coalition and Labor governments. 
The first major evaluation strategy was announced in April 1998. It was designed to enable the Howard Government 'to assess how well [the] Job Network was working and to provide information for later policy adjustment' (DEWR 2002b: 1). It was also to provide solid public evidence on the impact of such a radical and controversial shift in delivery arrangements. ${ }^{6}$ Three stages of evaluation were carried out. The first two reports on the implementation of the Job Network and early indicators of the impact of assistance were published in 2000 and 2001, while the final stage, released in 2002, focused on the lessons learnt from evaluating the Job Network, including its effectiveness in improving the employment prospects of jobseekers on a sustainable basis (DEWR 2000, 2001, 2002b). The evaluation strategy also required that the Productivity Commission review the policy framework for the Job Network.

Each major phase of the Job Network and of JSA had an extensive set of evaluation products (see Table 13.1). The investment was significant; by way of example, the evaluation strategy for the JSA in 2009 was costed at $\$ 8.3$ million (DEEWR 2009). The employment department managed all the evaluations in-house. Reports were based on both quantitative and qualitative analysis, which was conducted by both in-house experts in data analysis and evaluation and external consultants contracted by the department to undertake research and a major survey program of jobseekers, employment providers and employers. The department conducted several types of evaluations, as the OECD (2012: 228) observed: evaluations of specific programs, processes or jobseeker outcomes, estimates of the net impact of programs and broader strategic reviews employing a range of evidence. The strength of departmental administrative and program monitoring data was crucial to these evaluations. For example, data on jobseeker outcomes from employment assistance were collected from a post-program monitoring survey carried out three months (and sometimes six months) after assistance, and data on jobseeker characteristics were collected through the JSCI. Government income support data were also used. The extensive internal capability was built on an existing foundation of research and evaluation expertise, which had been enhanced following the introduction of the Job Network.

6 The driving force inside the Howard Government for these reforms was the Minister for Schools, Vocational Education and Training, David Kemp, who was known for his strong interest in gathering an evidence base to support the government's major reforms (Jarvie and Mercer 2015: 346, 351). 
The evaluation and monitoring activities were not only extensive; the findings were also very influential in modifying employment services. Both the OECD and external researchers have commented that a characteristic of Australia's employment services system was the high policy relevance of its evaluations and monitoring, with the one hesitancy being that the detailed evaluations and research have been done within the department, thus detailed evaluative data have not been subjected to external scrutiny (OECD 2012: 225).

The first three evaluations of the Job Network were particularly influential in the design of the second phase, known as the Active Participation Model (APM), which was introduced in 2003 and which responded to several of the early evaluation findings about the Job Network's performance (Table 13.1) (DEWR 2002b: 6; OECD 2012: 6). Through some key contract changes, the Howard Government accepted that the initial design of this radically new system had introduced unintended disincentives in the market to offer sustained services for 'difficult' jobseekers. In particular, the evaluation finding that the most disadvantaged jobseekers often received limited assistance from their provider underpinned the introduction of fixed service fees that were weighted towards those jobseekers who were most difficult to place (Davidson and Whiteford 2012: 58). Additionally, the Job Seeker Account, also introduced in 2003, established a quarantined funding pool to enable providers to expend funds on measures to address barriers to jobseekers. Under this new APM, greater oversight of provider activity was established, with information on provider contact with jobseekers and assistance provided now being reported to the employment department through a central information technology (IT) platform known as EA3000 (Davidson and Whiteford 2012: 58).

The design of the subsequent JSA model, introduced in 2009, was also considerably influenced by the department's evaluation findingsin particular, its net impact studies of labour market assistance. This included the decision to integrate seven existing programs into one and to concentrate assistance on the most disadvantaged jobseekers, given the evidence that the largest net impact from employment providers was associated with this category of the unemployed (OECD 2012: 224). The evaluation also showed that giving intensive support to clients for 12-18 months was too long, and this was subsequently cut back to six months. 
With the improved access to information following the introduction of the APM and the EA3000 platform in 2003, the department conducted seminars and published material on 'best practices' in the Job Network and internal analysis of detailed administrative data on employment outcomes (DEWR 2006; Davidson and Whiteford 2012: 66).

Given the significance of the government's investment in employment services and public scrutiny of this new approach, the employment department's evaluation and monitoring activities have been subject to ongoing external scrutiny, such as in the Productivity Commission's independent review in 2002 and in the two major reports by the OECD published in 2001 and 2012. In response to methodological issues identified by the Productivity Commission and the OECD in 2001, the employment department reassessed its approach to measuring the net employment gains provided by the Job Network (Thomas 2007: 15-16).

\section{The role of star ratings in achieving value for money}

As described earlier, improved value for money was undoubtedly achieved, although large efficiency gains and cost reductions took time to emerge (Finn, quoted in Borland 2014: 10). What was unexpected was that some of the mechanisms by which these were achieved were quite different to the original conception. For example, the original idea to choose providers on the basis of price tenders was quickly abandoned and replaced with tenders based on expected quality and outcomes. And one element, 'star ratings' for providers, has proved to be much more powerful than originally conceived.

Star ratings of providers - where providers were given a rating of between one and five stars (one star being poor and five stars being the highest rating) —were developed in 1999 with the assistance of the South Australian Centre for Economic Studies at Adelaide and Flinders universities. It was originally designed as a mechanism to signal to jobseekers the relative effectiveness of local providers. It was thus intended to drive competition between providers for clients. In practice, it very rapidly became the major mechanism of rewarding highly performing providers with more business and contracts and removing relatively poorly performing providers. Arguably, it became the key driver in achieving value for money in the employment services program for the past 15 years. 


\section{What are star ratings? How are they calculated?}

Star ratings are measures of provider performance adjusted for differences in jobseeker characteristics and local labour market conditions. The core features of the ratings have remained broadly constant since they were introduced, although the way they are calculated (including the weightings given to different variables), the distribution and the number of performance levels ${ }^{7}$ have varied with different phases of the employment services market.

The main element that determines the star rating of a provider at a site has been the short-term (three to six months) employment or educational outcomes of the jobseekers assisted by that provider at that site. There have also been efficiency variables, such as the time taken to 'place' jobseekers. For each provider site, the outcomes for jobseekers (disaggregated by their characteristics and local labour market conditions), together with other variables, each with a weight, are compared with the national estimate for all providers via a regression (PC 2002: 11.19). The differences at each provider site between the outcomes obtained and the expected outcomes are then allocated a star rating. Overall, the star rating reflects the value added by a provider compared with other providers.

Initially, under the Job Network, the distribution was fixed, so that, even if a provider improved their performance in absolute terms, they would receive an improved star rating only if they improved their performance compared with other providers. After 2009, following an expert review, ratings were based on the percentage difference between each site's performance and the national average, which reduced the number of providers falling into the lowest star bands, and was deemed fairer by providers.

The variables, and particularly the weightings given to them, varied significantly between contracts. Under the first phase of the Job Network (1999-2003), the two performance indicators for star ratings were:

1. The average time taken for jobseekers to achieve employment placements (which was designed to discourage 'parking' and the delaying of outcomes until higher outcome payments were available).

2. The proportions of jobseekers for whom outcome fees were paid (which was designed to reinforce the focus on job outcomes).

7 For a period, there were nine levels, with four 'half' stars and five full stars. 
Under the second phase-the APM (2003-09)—the greatest weight (attracting 60 per cent of the weightings within the star ratings) was given to outcomes attracting full outcome payments; generally, this was employment sufficient to take jobseekers off benefits for at least three to six months (see Table 13.2).

Table 13.2 Weightings used for the star ratings under the Active Participation Model, from 2005 (per cent)

\begin{tabular}{|l|l|l|l|}
\hline $\begin{array}{l}\text { Interim 'full' } \\
\text { outcomes }\end{array}$ & $\begin{array}{l}\text { Final 'full' } \\
\text { outcomes }\end{array}$ & $\begin{array}{l}\text { Intermediate } \\
\text { outcomes' }^{1}\end{array}$ & Job placements \\
\hline 40 & 20 & 20 & 10 \\
\hline
\end{tabular}

${ }^{1}$ Includes a 5 per cent weighting for educational outcomes.

Notes: Final 'full' outcomes are employment outcomes at 26 weeks; interim ones are at 13 weeks. Percentages do not add to 100.

Source: Davidson and Whiteford (2012: 66), based on Australian National Audit Office (ANAO 2005).

There were significant changes for the third phase under the JSA (2009-12). With the change from Howard's Liberal-National Coalition Government to the Rudd Labor Government in 2007, the star ratings system was revised, following a review by an expert reference group. The new calculation was much more complex and reflected the new Labor Government's focus on helping the most highly disadvantaged. Jobseekers were allocated to one of four 'streams', with one being relatively advantaged and four the most disadvantaged. For the purposes of star ratings, the outcomes achieved by the 'stream four' jobseekers were given four times the weight of those in stream one. There was also greater weighting of 26-week outcomes compared with 13-week outcomes, the introduction of a weighting for 'bonus outcomes' for employment obtained after training and a weighting for 'social outcomes' for jobseekers who completed stream four assistance (for details and changes from the previous system, see Appendix 13.2).

\section{How were star ratings used?}

As mentioned, initially, it was expected that the star ratings would be used by jobseekers to choose their provider. In line with this, from 2000, the employment department began to regularly publish star ratings of provider performance at over 1,400 individual sites. However, evaluations and jobseeker surveys regularly reported that the ratings were not influencing jobseekers (PC 2002: xxxii; Struyven 2004: 13). 
The employment department's 2007 evaluation reported that the regular release of ratings

coincided with a sustained improvement in the employment outcomes of jobseekers assisted by the Job Network. This improvement seemed greater than the level of improvement which could have realistically been expected from improvement in the labour market. (DEEWR 2007: 141)

It related this to the fact that the star ratings provided Job Network members with a strong incentive to focus on securing outcomes, job placements and interim outcomes because these were the primary performance measures used for the estimation of the ratings. However, later assessments concluded that their major impact was through their use in eliminating employment service providers that performed poorly (OECD 2012: 13). In tender rounds from 2000 onwards, providers with low star ratings lost business, which was reallocated to higher-performing providers and to some new entrants to the market.

The first major use of the star ratings for allocation of business occurred in the 2003 Job Network tender. In this tender round, the 'top' 60 per cent of providers based on star ratings had their contracts rolled over via an 'invitation to treat', leaving the bottom 40 per cent to compete with new entrants to the market (Davidson and Whiteford 2012: 65-6). ${ }^{8}$ After this tender, the number of organisations in the network was almost halved (to 109), with just seven new entrants (Finn 2008).

In 2006, the same process was repeated but a much lower proportion of the business was put out to tender; only 8 per cent of the (lowest-performing) providers were required to tender. This was partly to reduce the disruption that occurs from a major turnover of providers (Finn 2008). In place of regular and major tender processes, a system of rolling six-monthly performance reviews was introduced. Providers whose sites within a given area had consistently low star ratings had their market share reduced, sometimes to zero, with remaining business allocated by the department to other local providers or put out to tender.

In the JSA period (2009-12), star ratings continued to be used to determine future 'business shares' among local providers, but reallocations occurred on an 18-month cycle rather than the previous six-month cycle.

8 There was also a quality indicator that was expected to be used only rarely to adjust provider business shares. 
This was in response to the widespread criticism of the six-monthly cycle from providers on the grounds that it encouraged 'short-termism' in service delivery strategies and contributed to instability in the Job Network, especially a high turnover of staff who could not be guaranteed employment throughout the three-year tender period (O'Connor 2008, quoted in Davidson and Whiteford 2012: 65-6).

While the removal of poorer-performing providers is regarded as having had the greatest impact on the operation of the market, star ratings were useful in:

1. driving servicing efficiency in terms of reducing time to achieve outcomes for clients

2. encouraging provider focus on government priorities such as achieving outcomes for the most disadvantaged clients

3. reducing workload for the department associated with new contract periods (through rolling over of contracts).

From early on, this rating system was seen as performing an 'essential function' in the operation of the market (DEWR 2002a: 1). Both Coalition and Labor governments clearly viewed star ratings as a useful tool. Star ratings were gradually extended to other providers of employment-related services, with the first star ratings of provider performance published for Disability Employment Services in July 2006 and for Vocational Rehabilitation Services in 2007. Star ratings have also been continued for subsequent employment services arrangements under the JSA, 2012-15, and the Job Active 2015 model.

\section{Acceptance of star ratings}

While the introduction of star ratings had an immediate impact on effectiveness and cost (see Boxall 2003), it took some time before they were fully accepted by the industry. Originally, there was relatively little publicly available information on how the ratings were calculated and their composition, but, after the expert review in 2009, which led to greater transparency and less frequent reallocation of business, there was much greater acceptance. ${ }^{9}$ The Australian National Audit Office (ANAO) reported in a 2013-14 audit that ' $\mathrm{t}$ ] he approach to

9 Interview with S. Sinclair, Chief Executive Officer, National Employment Services Association, September 2015. 
measuring performance was generally accepted' by JSA providers and ' $\mathrm{t}]$ he Department has consulted with providers, and as a result aspects of the performance measures have been adjusted over time to improve its operation' (2014: 2.43).

There was general acceptance by the providers' peak body that the variables used, and the behaviour they reward, have been a key driver of performance. ${ }^{10}$ "The Star Rating System is defensible, with a sound mathematical basis, and essentially the best methodology to normalise each site and contract ESA (Employment Services Area)' (NESA 2015: 6).

One reason that star ratings and their component performance measures have driven performance is the confidence these employment providers and their peak body have had in the integrity of the system, which was managed by the Department of Employment. While there was always the danger of fraud (for example, DEEWR 2012), there was confidence in the data in the system. ${ }^{11}$ There was also confidence in the integrity of tender processes and mechanisms to get feedback on provider performance (for audit and fraud controls, see Box 13.1).

\section{Box 13.1 Audit and fraud controls}

- Tendering process: External probity adviser.

- Contract managers in each state. Providers assigned a risk rating, which determines the level of monitoring.

- IT system: Verifies providers' claims against social security data.

- Surveys of 400,000 jobseekers annually to gain feedback on their providers.

- Jobseeker complaints process and a 'tip-off' line.

- Internal and special audits.

Supplemented by broader controls, including the ANAO, parliamentary inquiries and the ombudsman.

Source: DEEWR (2012).

\section{Conclusion}

The outsourcing of service provision from government to private and community providers is conceptually simple and attractive to governments seeking to improve value for money. This example from Australia shows that improved value for money can be achieved, but it has required 
a complex system of management, including an intense focus on the performance of providers and the outcomes of the system. It has required experimentation and an acceptance that some elements have been more effective than others (Table 13.3).

Table 13.3 Employment services: Design features to drive better outcomes at lower cost

\begin{tabular}{|c|c|c|}
\hline System features & Effective? & Comments \\
\hline $\begin{array}{l}\text { Payment for } \\
\text { outcomes }\end{array}$ & $\begin{array}{l}\text { Yes - in focusing } \\
\text { providers on } \\
\text { getting employment } \\
\text { outcomes }\end{array}$ & $\begin{array}{l}\text { While it was effective, it required } \\
\text { constant fine-tuning and } \\
\text { supplementation with other mechanisms } \\
\text { to prevent 'parking' of hard-to-help } \\
\text { clients (where 'parking' means clients } \\
\text { were given very minimal assistance). } \\
\text { It also required constant monitoring } \\
\text { for fraud. }\end{array}$ \\
\hline $\begin{array}{l}\text { Targeting jobseekers } \\
\text { using the JSCl: An } \\
\text { assessment of how } \\
\text { difficult it will be for } \\
\text { the jobseeker to get } \\
\text { a job }\end{array}$ & $\begin{array}{l}\text { Generally, yes- } \\
\text { very important for } \\
\text { targeting support to } \\
\text { most disadvantaged }\end{array}$ & $\begin{array}{l}\text { Greater fees were paid when outcomes } \\
\text { were achieved for jobseekers with } \\
\text { a high JSCl. } \\
\text { Use of the JSCl in determining what } \\
\text { services a jobseeker would get and the } \\
\text { outcome fees paid changed between } \\
\text { phases/contracts. }\end{array}$ \\
\hline Tendering & $\begin{array}{l}\text { Effective when } \\
\text { tendering on quality } \\
\text { and outcomes } \\
\text { Ineffective when } \\
\text { tendering on price }\end{array}$ & $\begin{array}{l}\text { Tender rounds created major disruption } \\
\text { to services for clients when there } \\
\text { was large turnover of providers- } \\
\text { for example, in } 2009 \text {. }\end{array}$ \\
\hline $\begin{array}{l}\text { Jobseeker clients able } \\
\text { to choose provider }\end{array}$ & Not effective & $\begin{array}{l}\text { Jobseekers would tend to use closest } \\
\text { provider. Very few exercised choice } \\
\text { based on provider performance. }\end{array}$ \\
\hline $\begin{array}{l}\text { Star ratings of } \\
\text { providers }\end{array}$ & $\begin{array}{l}\text { Very effective in } \\
\text { driving value for } \\
\text { money over the } \\
\text { period 2000-12 }\end{array}$ & $\begin{array}{l}\text { Used by the employment department } \\
\text { to 'roll over' the contracts of best- } \\
\text { performing providers, awarding of } \\
\text { tenders and removal of poor performers. } \\
\text { Needed regular fine-tuning to reflect } \\
\text { changes in labour market conditions, } \\
\text { and constant monitoring for fraud. } \\
\text { Not effective in rating performance of } \\
\text { specialist providers working with very } \\
\text { hard-to-help clients. }\end{array}$ \\
\hline
\end{tabular}

Source: Author's work.

There have been many elements that have contributed to the results achieved in the privatised employment services system. One element was the fact that, while it was a radical change, the reform was built on previous experience with the outsourcing of some employment services and 
learnings from a long investment in research, evaluation and stakeholder engagement. Another important contributor was the targeting of highly disadvantaged jobseekers through the JSCI tool. The third element was its outcomes focus-its clear performance framework, payment for outcomes and, in particular, the use of provider star ratings in contract renewal and reallocation of business.

Underpinning all of these were the sustained and extensive public monitoring and evaluation, which provided the star ratings and other measures of provider and system outcomes, to enable regular fine-tuning of the system. In addition, it has required a core group of public officials with analytical and management capacity and who were trusted by providers; a strong audit and fraud system; and management based on a clear focus on the evidence of 'what works' and what needs to change and preparedness to modify the system in line with that evidence.

\section{References}

Australian National Audit Office (ANAO). 2005. Implementation of Job Network employment services contract 3, Department of Employment and Workplace Relations; Centrelink. Audit Report No. 6 2005-06. Canberra: ANAO.

Australian National Audit Office (ANAO). 2014. Management of services delivered by Job Services Australia, Department of Employment. Audit Report No. 37 2013-14. Canberra: ANAO.

Borland, J. 2014. 'Dealing with unemployment: What should be the role of labour market programs?' Evidence Base 4. Melbourne: Australia and New Zealand School of Government. Available from: journal. anzsog.edu.au (accessed 17 July 2017).

Boxall, P. 2003. Measuring performance: The state of the art. Presentation to the Australia and New Zealand School of Government.

Considine, M. and S. O'Sullivan. 2014. 'Introduction: Markets and the new welfare-Buying and selling the poor'. Social Policy and Administration 48(2)(April): 119-26. doi.org/10.1111/spol.12052. 
Davidson, P. and Whiteford, P. 2012. An overview of Australia's system of income and employment assistance for the unemployed. OECD Social, Employment and Migration Working Papers No. 129. Paris: OECD Publishing. doi.org/10.1787/5k8zk8q40lbw-en.

Department of Education, Employment and Workplace Relations (DEEWR). 2007. Active Participation Model Evaluation. July 20032006. November. Canberra: Australian Government.

Department of Education, Employment and Workplace Relations (DEEWR). 2009. Evaluation Strategy for Job Services Australia 2009 to 2012. Canberra: Australian Government.

Department of Education, Employment and Workplace Relations (DEEWR). 2011. Taskforce on Strengthening Government Service Delivery for Job Seekers. Report to the Secretary of the Department of Education, Employment and Workplace Relations and the Secretary of the Department of Human Services. 30 March. Canberra: Australian Government.

Department of Education, Employment and Workplace Relations (DEEWR). 2012. Job Services Australia provider brokered outcomes. Audit Report. Canberra: Australian Government.

Department of Employment and Workplace Relations (DEWR). 2000. Job Network evaluation stage one: Implementation and market development. Evaluation and Program Performance Branch Labour Market Policy Group EPPB Report 1/2000. Canberra: Australian Government.

Department of Employment and Workplace Relations (DEWR). 2001. Job Network evaluation stage two: Progress report. Evaluation and Program Performance Branch Labour Market Policy Group EPPB Report 2/2001. Canberra: Australian Government.

Department of Employment and Workplace Relations (DEWR). 2002a. Government Response to the Productivity Commission Independent Review of Job Network. Canberra: Australian Government.

Department of Employment and Workplace Relations (DEWR). 2002b. Job Network evaluation stage 3: Effectiveness report. Report 1/2002. Canberra: Australian Government. 
Department of Employment and Workplace Relations (DEWR). 2003. Intensive assistance and job search training: A net impact study. Evaluation and Program Performance Branch, Employment Analysis and Evaluation Group December EPPB Report 2/2003. Canberra: Australian Government.

Department of Employment and Workplace Relations (DEWR). 2006. Job Network Best Practice. Canberra: Australian Government.

Finn, D. 2008. The British 'Welfare Market': Lessons from contracting out welfare to work programmes in Australia and the Netherlands. York, UK: Joseph Rowntree Foundation. Available from: www.jrf.org.uk (accessed 17 July 2017).

Jarvie, W. and T. Mercer. 2015. 'Championing change in a highly contested policy area: The literacy reforms of David Kemp, 1996-2001'. In J. Wanna, E. A. Lindquist and P. Marshall (eds) New Accountabilities, New Challenges. Canberra: ANU Press.

National Employment Services Association (NESA). 2015. Employment Services Australia: Roadmap for the future (detailed proposals). Melbourne: NESA. Available from: nesa.com.au (accessed 17 July 2017).

O'Connor, B. 2008. The Future of Employment Services in Australia. Canberra: Department of Education, Employment and Workplace Relations.

Organisation for Economic Co-operation and Development (OECD). 2001. Innovations in Labour Market Policies: The Australian way. Paris: OECD Publishing.

Organisation for Economic Co-operation and Development (OECD). 2012. Activating Jobseekers: How Australia does it. Paris: OECD Publishing.

Productivity Commission (PC). 2002. Independent review of the Job Network inquiry report. Report No. 21, June. Melbourne: Productivity Commission.

Struyven, L. 2004. Design choices in market competition for employment services for the long-term unemployed. OECD Social, Employment and Migration Working Papers No. 21. Paris: OECD Publishing. 
Thomas, M. 2007. A review of developments in the Job Network. Research Paper No. 12, 2007-08, 24 December. Canberra: Department of Parliamentary Services, Parliament of Australia.

\section{Appendix 13.1 The role of the Department of Employment}

The Department of Employment (with different titles since 1998) administers the employment services market by:

1. defining purchaser provider arrangements and detailed in-service contracts with private and community-based providers

2. organising public tenders and the award of contracts

3. monitoring and supervision of the contract implementation.

In 2012, the department oversaw contracts with more than 100 private and community-sector providers. It paid providers fees for contracted services and placement outcomes, supervised contract implementation at the level of the department and through its state, territory and district offices and monitored provider performance at the level of about 2,300 individual sites through star ratings assessments and other performance indicators (OECD 2012: 63, 75).

\section{Appendix 13.2 Star ratings for the JSA, 2009-12}

Appendix Table A13.1 Weightings used for JSA star ratings (per cent)

\begin{tabular}{|l|r|r|r|r|}
\hline & $\begin{array}{c}\text { Stream 1 } \\
\text { (overall } \\
\text { weighting } \\
\text { of 10\%) }\end{array}$ & $\begin{array}{c}\text { Stream 2 } \\
\text { (overall } \\
\text { weighting } \\
\text { of 20\%) }\end{array}$ & $\begin{array}{c}\text { Stream 3 } \\
\text { (overall } \\
\text { weighting } \\
\text { of 30\%) }\end{array}$ & $\begin{array}{c}\text { Stream 4 } \\
\text { (overall } \\
\text { weighting } \\
\text { of 40\%) }\end{array}$ \\
\hline KPI1: 'Speed to place' & 18 & 7 & 5 & 2 \\
\hline $\begin{array}{l}\text { KPI2: Interim 'full' } \\
\text { outcomes }\end{array}$ & 10 & 23 & 25 & 19 \\
\hline $\begin{array}{l}\text { KPI2: Final 'full' } \\
\text { outcomes }\end{array}$ & 10 & 30 & 30 & 21 \\
\hline
\end{tabular}




\begin{tabular}{|l|r|r|r|r|}
\hline & $\begin{array}{c}\text { Stream 1 } \\
\text { (overall } \\
\text { weighting } \\
\text { of 10\%) }\end{array}$ & $\begin{array}{c}\text { Stream 2 } \\
\text { (overall } \\
\text { weighting } \\
\text { of 20\%) }\end{array}$ & $\begin{array}{c}\text { Stream 3 } \\
\text { (overall } \\
\text { weighting } \\
\text { of 30\%) }\end{array}$ & \multicolumn{1}{c|}{$\begin{array}{c}\text { Stream 4 } \\
\text { (overall } \\
\text { weighting } \\
\text { of 40\%) }\end{array}$} \\
\hline $\begin{array}{l}\text { KPI2: Intermediate } \\
\text { outcomes }\end{array}$ & 10 & 20 & 20 & 18 \\
\hline KPI2: Paid placements & 42 & 10 & 10 & 10 \\
\hline $\begin{array}{l}\text { KPI2: Completion } \\
\text { of Stream 4 }\end{array}$ & n.a. & n.a. & n.a. & 20 \\
\hline $\begin{array}{l}\text { KPI2: 'Bonus' } \\
\text { outcomes }\end{array}$ & 10 & 10 & 10 & 10 \\
\hline Total & 100 & 100 & 100 & 100 \\
\hline
\end{tabular}

Notes: 'Speed to place' refers to the time taken to achieve outcomes; 'interim and final full outcomes' refers to employment outcomes sufficient to remove entitlements to income support or participation in an educational program that is sustained for 13 and 26 weeks, respectively; 'intermediate outcomes' refers to part-time employment or a less substantial educational program; 'paid placements' refers to employment that is sustained for at least 50 hours; 'bonus outcomes' refers to employment outcomes attained within 12 months of completion of a qualifying training program or outcomes attained by Indigenous people.

Source: Davidson and Whitehead (2012: 80).

Changes in the star ratings framework compared with the Job Network framework include:

- greater complexity, with 36 weights (previously only seven weights)

- higher weighting on outcomes attained by the most disadvantaged jobseekers: 40 per cent for those in stream four, compared with 10 per cent for those in stream one (previously, outcomes achieved after one year of unemployment or three years had the same weight)

- higher weighting on 26-week outcomes compared with 13-week outcomes (previously, 40 per cent on 13-week outcomes and 20 per cent on 26-week outcomes)

- 10 per cent weight on 'bonus outcomes', which include training/ apprenticeship outcomes (previously, there was a 10 per cent weight on the disadvantaged jobseeker share in the 13-week outcomes)

- weight on 'social outcomes' for jobseekers who complete stream four assistance (previously, 'social outcomes' were paid for completion of two years in the personal support program). 
This text is taken from Value for Money: Budget and financial management reform in the People's Republic of China, Taiwan and Australia, edited by Andrew Podger, Tsai-tsu Su, John Wanna, Hon S. Chan and Meili Niu, published 2018 by ANU Press, The Australian National University, Canberra, Australia. 